\title{
Gene expression pattern of digestive and antioxidant enzymes during the larval development of reared Atlantic bluefin tuna (ABFT), Thunnus thynnus L.
}

\begin{abstract}
David Mazurais ${ }^{1, *}$, Denis Covès ${ }^{2}$, Nikos Papandroulakis $^{4}$, Aurelio Ortega $^{3}$, Elisabeth Desbruyeres ${ }^{1}$, Christine Huelvan ${ }^{1}$, Marie Madeleine Le Gall ${ }^{1}$, Fernando De la Gandara ${ }^{3}$, Chantal Louise Cahu ${ }^{1}$
\end{abstract}

\footnotetext{
${ }_{1}^{1}$ Unité de Physiologie Fonctionnelle des Organismes Marins, Ifremer, Plouzané, France

2 Laboratoire Aquacole du Languedoc Roussillon, Ifremer, Palavas, France

3 Instituto Espanol de Oceanografia (IEO), Centro Oceanografico de Murcia, Puerto de Mazarron, Spain

${ }^{4}$ Institute of Aquaculture, Hellenic Centre of Marine Research, Heraklion, Greece

*: Corresponding author : David Mazurais, email address : david.mazurais@ifremer.fr
}

\begin{abstract}
:
The aim of this study was to determine whether mortality observed during the larval development of reared bluefin tuna (Thunnus thynnus) could be related to improper expression profiles of key genes involved in digestive or antioxidant response capabilities. Tuna larvae were sampled at hatching, 2, 5, 10,15 and $20 \mathrm{dph}$ (days post hatching) for the relative quantification of transcripts encoded by genes involved in digestive [trypsinogen 1 (TRYP1), alpha-amylase (AMY), aminopeptidase N (ANPEP)] and antioxidant [catalase (CAT)] functions. The levels of expression of ANPEP related to the development and maturation of intestinal function increased from 5 to $20 \mathrm{dph}$. Furthermore, AMY and TRYP1 genes, which are pancreatic enzymes implicated in carbohydrate and peptide digestions exhibit a typical peak of expression at 5 and 15 dph respectively. The antioxidant enzyme, CAT, exhibited higher mRNA levels during the first stage of larval development. In conclusion, our investigation indicates that the expression of genes involved in digestive and antioxidant physiological processes followed typical patterns which could not explain high mortality rate observed during the first stage of larval development.
\end{abstract}

Keywords: tuna ; Gene ; Expression ; Development ; Digestion ; antioxidant 


\section{Introduction}

The wild population of Atlantic bluefin tuna (ABFT), Thunnus thynnus (L., 1758), in the Mediterranean, which is appraisal for the quality of its flesh, has experienced severe declines the last decades essentially due to overexploitation (FAO 2008). In order to reduce the pressure on this species and aid in its conservation, the European Union has funded projects, such as Selfdott (FP7-KBBE-2007-1) whose aim has been to breed bluefin tuna and provide the basis for future ecologically sustainable aquaculture of this threatened species. In this context, efforts have been given to obtain fertilized and viable eggs from adapted broodstock and ship them to larval rearing facilities for the production of juveniles. However, while spawnings could be obtained in captivity, the problem which still remain is the high level of mortality, just after first feeding and more generally during the early larval stages of development (De La Gandara, Mylonas, Coves, Ortega, Bridges, Belmonte, Vassallo-Agius, Papandroulakis, Rosenfeld, Tandler, Medina, Demetrio, Corriero, Fauvel, Falcon, Sveinsvoll, Ghysen, Deguara \& Gordin 2010). In the framework of SELFDOTT project, larval rearing trials were performed in different conditions of density and feeding: in pseudo green water, in mesocosm, or intensive clear water conditions. Whatever the conditions, around $50 \%$ of larvae died at 5 day post-hatching (dph), i.e. 2 days after first feeding, and less than $1 \%$ of larvae survived up to $20 \mathrm{dph}$ (SELFDOTT 2009). Some reared larvae lots exhibit high percentage of malformation or skeletal deformities, but the reasons explaining those abnormal development still remain unclear (Cataudella, Boglione, Caprioli, Vitalini, Pulcini, Cataldi, Pennacchi, Amoroso, Prestinicola, Marroncini, Corriero, Ugolini, De Marzi, Spanò, Consiglio, Ceravolo \& Caggiano 2011). First data related to feeding sequence of bluefin tuna yolk sac larvae suggested that mortality observed during the first stages of life could be partly due to nutritional deficiencies (De La Gandara et al. 2010). It is well known that several nutrients such as phospholipids and vitamins play an important role during the ontogeny of marine fish (Cahu, Zambonino-Infante \& Takeuchi 2003 ; Cahu, Zambonino-Infante \& Barbosa 2003 ; Mazurais, Darias, Gouillou-Coustans, Le Gall, Huelvan, Desbruyères, Quazuguel, Cahu \& Zambonino-Infante 2008) including Pacific bluefin tuna Thunnus orientalis (Seoka, Kurata, Tamagawa, Biswas, Biswas, Yong, Kim, Ji, Takii \& Kumal 2008). Nevertheless, these beneficial effects require an optimal uptake that depends on the maturation of the digestive tract (Zambonino-Infante \& Cahu 2007). Nutritional deficiencies and resulting mortality could also be related to early perturbations of the protective mechanisms against oxidation and antioxidant pathways, during larval development (Murata, Sakai, Yamauchi, Ito, Tsuda, Yoshida \& Fukudome 1996; Mourente, Tocher, Diaz, Grau \& Pastor 1999). Indeed, numerous studies indicated that lipid and polyunsaturated fatty acid peroxidation is deleterious for biomembranes and is implicated in several pathological conditions in fish including larval stages (Koshio, Ackman \& Lall 1994; Fontagne, Bazin, Breque, Vachot, Bernarde, Rouault \& Bergot 2006).

One of the major bottlenecks to rely bluefin tuna larvae mortalities to the dysfunction of such biological processes is to characterize their functionality from small amounts of biological materials originated from available larvae. One way to tackle this question is to investigate at transcriptomic level the expression of key genes known to be involved in these specific processes since quantitative Polymerase Chain Reaction (qPCR) does not require massive amounts of tissues. Moreover, previous data obtained in different marine fish species have already described the typical expression or activity patterns of key actors involved in the digestive (pancreatic enzymes: trypsinogen 1 [TRYP1], alpha-amylase [AMY] and intestinal enzyme: aminopeptidase $\mathrm{N}$ [ANPEP]) and antioxidant (catalase [CAT]) functions during harmonious larval ontogenesis ( Zambonino-Infante \& Cahu 2007; Kalaimani, Chakravarthy, Shanmugham, Thirunavukkarasu, Alavandi \& Santiago 2008; Kortner, Overrein, Oie, Kjorsvik, Bardal, Wold \& Arukwe 2011; Galaviz, Garcia-Ortega, Gisbert, Lopez \& Gasca 2012). 
Growth, development as well as survival were related to a proper maturation of the digestive function in several marine fish larvae (Ma, Cahu, Zambonino, Yu, Duan, Le Gall \& Mai 2005; Kortner, Overrein, Oie, Kjorsvik, Bardal, Wold \& Arukwe 2011) and disturbance in this maturation process has been shown to be lethal (Cahu \& Zambonino-Infante 1995). In the present study, we have investigated the time-course expression of these enzymes as well as myosin heavy chain gene (MYH2) in order to provide an overview on the molecular ontogeny of digestive and antioxidant capability with the associated growth and rely possible effects on survival rate during bluefin tuna larvae development. This work based on qPCR experiments has required previous cloning of partial cDNA encoding the investigated genes.

\section{Materials and methods}

\subsection{Experimental animals}

The eggs were obtained from ABFT broodstock of Caladeros del Mediterráneo S.A. (Cartagena, Spain) and transported to the different hatcheries participating in the SELFDOTT project. A part of the larvae was reared in pseudo green water in the local facilities in IEO (Puerto de Mazarron, Spain). The "pseudo green water" method is based on the control of light intensity, photophase and feed supply, with an addition of microalgae to maintain constant their concentration in the rearing system (Papandroulakis, Divanach \& Kentouri 2002). A second part was sent to HCMR (Heraklion, Greece), where the larvae were reared in mesocosm (Papandroulakis, Stefanakis, Anastasiadis, Ballesteros, Papadakis, Janssen, Vassilakis, Strakantounas \& Divanach 2011) and also in pseudo green water. Another part of the eggs shipped to Ifremer (Palavas, France), where the larvae were reared in clear water. Briefly, the feeding sequence in all conditions was based on enriched rotifers and Artemia, while in pseudo green and mesocosm rearing yolk sac sea bream larvae being provided as prey from $18 \mathrm{dph}$. Complete rearing conditions are described in Gatesoupe et al. (2013).

Pool of larvae were sampled at hatching and at 2 (mouth opening), 5, 10, 15 and/or $20 \mathrm{dph}$, depending on the rearing conditions, following Table 1. Larvae were kept in RNA later until RNA extraction. Larvae (20 for each rearing condition) used for length determination were anesthetized $(0.02 \%$ phenoxyethanol) and total lengths were measured.

\subsection{RNA extraction and cDNA cloning}

The RNA later was removed from the samples and TRIzol Reagent (Invitrogen, Breda, Netherlands) was used for total RNA extraction. Since biological matter for samples at some sampling date was insufficient to extract enough RNA for retro-transcription, some have been pooled (Table 1). The purity and integrity of extracted RNA was controlled using the NanoDrop ND-1000 and Agilent's 2100 Bioanalyzer, respectively.

For cDNA cloning, $1 \mu \mathrm{g}$ total RNA originated from a pool of larvae sampled at different developmental stages was reverse-transcribed with the QuantiTect ${ }^{\circledR}$ Reverse Transcription kit (Qiagen, Courtaboeuf, France). Primers used for cloning EF1a (housekeeping gene), TRYP1, AMY, ANPEP, and CAT and annealing temperatures are given in table 2. Primers were designed in most conserved regions regarding alignment of orthologous sequences registered in Genbank.

Fifty microliters of amplification reaction mixture contained $50 \mathrm{ng}$ cDNA, $2.5 \mathrm{U}$ of Taq polymerase (Qiagen, Courtaboeuf, France), 40 nM dNTPs (Eurogentec, Seraing Belgium), $50 \mathrm{pmol}$ of each primer, and $1 \times$ buffer solution. PCR conditions were performed in a thermocycler (Techne, Staffordshire, UK) as follows: initial denaturation at $94{ }^{\circ} \mathrm{C}$ for $30 \mathrm{~s}$, 
followed by 40 cycles including denaturation at $94{ }^{\circ} \mathrm{C}$ for $1 \mathrm{~min}$, annealing at specific enzyme temperatures for $1 \mathrm{~min}$, and $1 \mathrm{~min}$ elongation at $72^{\circ} \mathrm{C}$. A final extension cycle was performed at $72{ }^{\circ} \mathrm{C}$ for $7 \mathrm{~min}$. PCR fragments of predicted size were cloned according the protocol of Topo TA Cloning kit (Invitrogen, Breda, Netherlands) into TOP 10F' thermo-competent cells, using the $p C R$ 2.1-TOPO as vector. Plasmids were purified by mini-prep according to UltraClean Mini Plasmid kit (MO-BIO, Carlsbad CA, USA) and next sequenced by MilleGen (Labège, France). The resulting sequences for the different partial cDNA were registered in Genbank under access number listed in Table 2.

\subsection{Quantitative PCR analysis}

For each pool of larvae originated from the different developmental stage, total RNA were separately reverse transcribed into cDNA with the QuantiTect ${ }^{\circledR}$ Reverse Transcription kit (Qiagen, Courtaboeuf, France) including a genomic DNA elimination reaction. Relative mRNA levels of investigated genes were determined by real time PCR through the application of the 2(-DeltaDeltaCt) analysis methods using elongation factor-1 alpha (EF1a) as a reference gene since it did not exhibit any significant variation between developmental stages and has been already successfully used in similar time course experiments in other species (Mazurais et al. 2008). Primers were designed using primer 3 program (http://frodo.wi.mit.edu/primer3/input.htm).

The real time PCR reaction was carried out in an I-cycler with an optical module (Bio-Rad, Hercules, CA, USA) in a final volume of $15 \mu$ l containing $7,5 \mu \mathrm{l}$ of SYBR Green Supermix (Biorad, Hercules, CA, USA), $5 \mathrm{~nm}$ of each primer (listed in table 1) and 0,5 $\mu \mathrm{l}$ of cDNA (1/100 diluted). The PCR program consisted of an initial DNA denaturation of $94^{\circ} \mathrm{C}$ for $90 \mathrm{~s}$, followed by 45 cycles at $95^{\circ} \mathrm{C}$ for $30 \mathrm{~s}, 60^{\circ} \mathrm{C}$ for $60 \mathrm{~s}$ and 80 cycles at $95^{\circ} \mathrm{C}$ for $10 \mathrm{~s}$. Each sample is run in technical triplicates to provide tight data through elimination of drop-out wells.

\subsection{Statistical analysis}

All the results are presented as mean values of all measures obtained for one stage of development and corresponding standard deviations (SD). Relative mRNA levels were compared between developmental stages by one factor analysis of variance $(P<0.05)$ with Fisher test as post-hoc comparison using the Statistica biosoft 8.0. The amount of replicates for each sampling date was too low to perform a two way ANOVA considering "rearing condition" as second factor.

\section{Results}

\section{1. cDNA cloning}

Partial cDNA sequences obtained from EF1a, TRYP1, AMY, ANPEP, and CAT primers were compared to those available in the GenBank database. These comparisons assigned the obtained fragments to the expected orthologous genes from other species (Table 3). 


\subsection{Somatic growth}

The bluefin tuna growth investigated through total length estimation during the first 20 days post hatching exhibit exponential pattern (Fig. 1). This growth curve is confirmed by MYH2 expression pattern (Fig. 2A).

\subsection{Gene expression pattern}

Statistical analysis revealed that all investigated genes (excepted EF1a) exhibit significant variation during bluefin tuna development. Post-hoc analysis allowed to decipher the significant variation of the different transcripts throughout larval ontogenesis.

\subsubsection{Pancreatic digestive enzyme expressions (AMY, TRYP1)}

AMY mRNA levels significantly increased between hatching and 5 dph then decreased until $20 \mathrm{dph}$ (Fig. 2B). The pattern of TRYP1 expression exhibit similar increase from hatching until 5 dph but then differ from AMY pattern since TRYP1 mRNA levels remained high until $15 \mathrm{dph}$ before exhibiting non significant decrease at 20dph (Fig. 2C).

\subsubsection{Intestinal enzyme expression (ANPEP)}

Aminopeptidase mRNA levels, relatively low at hatching, mouth opening stages and $5 \mathrm{dph}$ increased significantly from $5 \mathrm{dph}$ to $10 \mathrm{dph}$ and remained constant afterwards (Fig. 2D).

Antioxidant gene expression (CAT): Catalase gene exhibited higher mRNA levels at the early stages of larval development, from hatching to $5 \mathrm{dph}$. Afterwards, the amount of transcripts decreased steadily but significantly until day 20 post hatching (Fig. 2E).

\section{Discussion}

First attempts to rear bluefin tuna during the larval stages from captivity adapted broodstock are characterized by complete mortality beyond the first two months of life (De La Gandara et al. 2010). This high mortality rate has been suggested to be at least partly related to nutritional deficiencies since the feeding sequence was shown to influence both survival and growth (De La Gandara et al. 2010). Several studies have reported that growth and survival rates during larval stages of different species were related to the nutritional value of the feed and/or food digestion, nutrient absorption and metabolism (Fuentes, Sanchez, Lago, Iglesias, Pazos \& Linares 2012; Ogata \& Kurokura 2012; Yu, Ai, Mai, Ma, Cahu \& Zambonino-Infante 2012). In the present experiment, bluefin tuna larvae were fed enriched preys (rotifer and Artemia nauplii) following specific sequence in order to attempt to meet the energetic and nutritional needs at that stage. The exponential growth curve observed during the first 20 days post-hatching through total length determination could suggest that this sequence is adapted for bluefin tuna larvae development. Exponential somatic growth is also revealed by our investigation of $\mathrm{MYH} 2$ gene expression pattern. $\mathrm{MYH} 2$ can indeed be considered as a molecular marker of somatic growth since its expression has been shown to increase with muscular tissue formation throughout fish larvae development (Overturf \& Hardy 2001; Imsland, Le Francois, Lamarre, Ditlecadet, Sigurosson \& Foss 2006). However, the high mortality values observed during the first twenty days post hatching reveal impairment of the developmental process. One way to get information about the nature of larval ontogenic 
dysfunction is to follow the maturation of the digestive tract. Fish larvae are indeed physiologically immature at hatching and their harmonious development must be associated with the maturation of several functions including digestive function which is also influenced by the quality of the feed (Cahu \& Zambonino-Infante 1995; Overturf \& Hardy 2001). In the present study, the ontogenesis of pancreatic and intestinal digestive functions were investigated through analysis of specific gene expression since not enough biological materials were available for biochemical analysis. The cloning of bluefin tuna orthologs of AMY, TRYP1 and ANPEP genes allow to make use of new molecular tools useful for a better characterization of digestive tract maturation at larval stage in this species. It is in fact admitted that great part of the gastrointestinal development is genetically programmed and therefore can be tackled through investigation of the levels of transcripts encoding key actors of digestive function (Zambonino-Infante \& Cahu 2001). The profiles of pancreatic genes expression (AMY and TRYP1) observed in the present experiment in bluefin tuna follow a pattern similar to that commonly observed in carnivorous fish such as sea bass. Nevertheless the higher growth, peak and decline of the profile observed in tuna indicated the fast development of the species. Amylase hydrolysis is the first step in carbohydrate digestion, and trypsin hydrolyse is the first step of protein digestion before pepsin action. The amylase expression exhibited a peak very early after feeding and then sharply decreased, contrary to omnivorous species such as yellow croaker Pseudoaciaena crocea in which the decrease is lower (Ma, Cahu, Zambonino, Yu, Duan, Le Gall \& Mai 2005). Trypsin expression, still present at mouth opening, increased from first feeding and maintained at high level. Thus the pattern of these two enzymes is characteristic of carnivorous feeding. Moreover, the increase in AMY and TRYP1 gene expression occurred within the first three days post hatching while the pancreas, liver, gall bladder is formed (Kaji, Tanaka, Takahashi, Oka \& Ishibashi 1996). In the same way, we found an increase in the expression of aminopeptidase gene involved in the digestion of protein in intestinal microvillus one week earlier than in sea bass (Cahu \& Zambonino-Infante 1994) or sole (Ribeiro, ZamboninoInfante, Cahu \& Dinis 1999), showing a rapid development of intestinal microvilli. This result is in total agreement with previous morphological and enzymatic observations in bluefin tuna demonstrating precocity in the development of its digestive system which could be related to an early appearance of piscivory and to the high growth potential of tuna larvae (Kaji et al. 1996; Miyashita, Kato, Sawada, Murata, Ishitani, Shimizu, Yamamoto \& Kumai 1998).

Mortality and poor development during larval stages has been attributed to antioxidant status in Solea senegalensis (Fernandez-Diaz, Kopecka, Canavate, Sarasquete \& Sole 2006). The antioxidant defense system, protecting cells against reactive oxygen species (ROS), include several enzymes, such as superoxide dismutase, catalase, glutathione reductase and glutathione-S-transferase, associated with anti-oxidant vitamins, such as alpha tocopherol (vitamin E), retinoic acid (vitamin A), ascorbic acid (vitamin C) present in yolk and provided by diet as soon as first feeding. This cell protection system must be efficient especially during early stages, when unsaturated fatty acids, particularly sensitive to oxidation, are present at high level, and stresses induced by changes are numerous: change from endogenous to exogenous feeding, diet changes, high growth and metamorphoses (Fernandez-Diaz et al. 2006; Kalaimani et al. 2008).

Tuna eggs and young larvae are particularly rich in lipid, around $30 \%$ of dry mass at hatching, decreasing to $19 \%$ at $4 \mathrm{dph}$, when larvae start feeding. Docosahexaenoic acid (DHA) represents a large and increasing proportion of lipids during this period: 10 to $23 \%$ of total lipids, the other main polyunsaturated n-3 fatty acid, the eicosapentaenoic acid (EPA) representing 6,4 to $4,7 \%$ of total lipids from $0 \mathrm{dph}$ to $4 \mathrm{dph}$ (Morais, Mourente, Ortega, Tocher \& Tocher 2011). Among antioxidant enzymes, we chose to analyze the variation in catalase (CAT) gene expression. Indeed, catalase acts with superoxide dismutase in the inactivation of superoxide and hydrogen peroxide. The high level of CAT expression observed at hatching, mouth opening and $5 \mathrm{dph}$ stages was associated with the protection of polyunsaturated lipids, in high concentration at these stages. The decrease in CAT during 
developing stages was consistent with the decrease in concentration of polyunsatured lipids. This pattern of CAT expression in tuna is very similar to that observed in Lates calcarifer (Kalaimani et al. 2008).

In conclusion, we found in bluefin tuna larvae a classical pattern of proper digestive functions development although presenting a much faster evolution than in other carnivorous species, and the biomarker of antioxidant status revealed also a pattern similar to other species. Consequently, the present data can not explain the high mortality of larvae by a defect in both the maturation of the digestive tract and the antioxidant status.

\section{Acknowledgements}

This work was carried out with financial support from the Commission of the European Communities (RTD programme SELFDOTT, GA 212797). It does not necessarily reflect the Commission's views and in no way anticipates its future policy in this area.

\section{References}

Cahu C.L., Zambonino-Infante J. \& Takeuchi T. (2003) Nutritional components affecting skeletal development in fish larvae. Aquaculture, 227, 245-258.

Cahu C.L. \& Zambonino-Infante J.L. (1994) Early weaning of sea bass (dicentrarchus labrax) larvae with a compound diet - effect on digestive enzymes. Comparative Biochemistry and Physiology a-Physiology, 109, 213-222.

Cahu C.L. \& Zambonino-Infante J.L. (1995) Maturation of the pancreatic and intestinal digestive functions in sea bass (Dicentrarchus labrax): Effect of weaning with different protein sources. Fish Physiology and Biochemistry, 14, 431-437.

Cahu C.L., Zambonino-Infante J.L. \& Barbosa V. (2003) Effect of dietary phospholipid level and phospholipid:neutral lipid value on the development of sea bass (Dicentrarchus labrax) larvae fed a compound diet. British Journal of Nutrition, 90, 21-28.

Cataudella S., Boglione C., Caprioli R., Vitalini V., Pulcini D., Cataldi E., Pennacchi Y., Amoroso G., Prestinicola L., Marroncini M., Corriero A., Ugolini R., De Marzi P., Spanò A., Consiglio A., Ceravolo V. \& Caggiano M. (2011) Aquaculture of atlantic Bluefin tuna (Thunnus thynnus I. 1758): increasing morphological knowledge on larvae and juveniles. In: Aquaculture Europe, The annual meeting of the European Aquaculture Society, Rhodes, Greece, pp. 171-172.

De La Gandara F., Mylonas C., Coves D., Ortega A., Bridges C.R., Belmonte R.A., VassalloAgius R., Papandroulakis N., Rosenfeld H., Tandler A., Medina A., Demetrio A., Corriero A., Fauvel C., Falcon J., Sveinsvoll K., Ghysen A., Deguara S. \& Gordin H. (2010) Seedling production of Atlantic bluefin tuna (ABFT) Thunnus thynnus. The selfdott project. In: Joint International symposium of Kinki University and Setouchi town on the 40th anniversary of Pacific bluefin tuna aquaculture, Towards the sustainable aquaculture of bluefin tuna (ed Dr. Shigeru Miyashita DKT, Dr. Wataru Sakamoto, Dr. Amal Biswas). Kinki University Press, Amami, Japan, pp. 45-52.

FAO (2008) Capture based aquaculture. Global overview. In: FAO Fisheries Technical Paper , pp. 314 p. 
Fernandez-Diaz C., Kopecka J., Canavate J.P., Sarasquete C. \& Sole M. (2006) Variations on development and stress defences in Solea senegalensis larvae fed on live and microencapsulated diets. Aquaculture, 251, 573-584.

Fontagne S., Bazin D., Breque J., Vachot C., Bernarde C., Rouault T. \& Bergot P. (2006) Effects of dietary oxidized lipid and vitamin $A$ on the early development and antioxidant status of Siberian sturgeon (Acipenser baeri) larvae. Aquaculture, 257, 400-411.

Fuentes L., Sanchez F.J., Lago M.J., Iglesias J., Pazos G. \& Linares F. (2012) Growth and survival of Octopus vulgaris (Cuvier 1797) paralarvae fed on three Artemia-based diets complemented with frozen fish flakes, crushed zooplankton and marine microalgae. Scientia Marina, 75, 771-777.

Galaviz M.A., Garcia-Ortega A., Gisbert E., Lopez L.M. \& Gasca A.G. (2012) Expression and activity of trypsin and pepsin during larval development of the spotted rose snapper Lutjanus guttatus. Comparative Biochemistry and Physiology Part B: Biochemistry and Molecular Biology, 161, 9-16.

Gatesoupe J., Coves D., Ortega A., Papandroulakis N., Vadstein O., De La Gandara F. (2013). A spatiotemporal study of bacterial community profiles associated with Atlantic bluefin tuna larvae, Thunnus thynnus L., in three Mediterranean hatcheries. Aquaculture Research, 44, 1511-1523.

Imsland A.K., Le Francois N.R., Lamarre S.G., Ditlecadet D., Sigurosson S. \& Foss A. (2006) Myosin expression levels and enzyme activity in juvenile spotted wolffish (Anarhichas minor) muscle: a method for monitoring growth rates. Canadian Journal of Fisheries and Aquatic Sciences, 63, 1959-1967.

Kaji T., Tanaka M., Takahashi Y., Oka M. \& Ishibashi N. (1996) Preliminary observations on development of Pacific bluefin tuna Thunnus thynnus (Scombridae) larvae reared in the laboratory, with special reference to the digestive system. Marine and Freshwater Research, 47, 261-269.

Kalaimani N., Chakravarthy N., Shanmugham R., Thirunavukkarasu A., Alavandi S. \& Santiago T. (2008) Anti-oxidant status in embryonic, post-hatch and larval stages of Asian seabass (Lates calcarifer). Fish Physiology and Biochemistry, 34, 151-158.

Kortner T.M., Overrein I., Oie G., Kjorsvik E., Bardal T., Wold P.-A. \& Arukwe A. (2011) Molecular ontogenesis of digestive capability and associated endocrine control in Atlantic cod (Gadus morhua) larvae. Comparative Biochemistry and Physiology - Part A: Molecular and Integrative Physiology, 160, 190-199.

Koshio S., Ackman R.G. \& Lall S.P. (1994) Effects of Oxidized Herring and Canola Oils in Diets on Growth, Survival, and Flavor of Atlantic Salmon, Salmo salar. Journal of Agricultural and Food Chemistry, 42, 1164-1169.

Ma H.M., Cahu C., Zambonino J., Yu H.R., Duan Q.Y., Le Gall M.M. \& Mai K. (2005) Activities of selected digestive enzymes during larval development of large yellow croaker (Pseudosciaena crocea). Aquaculture, 245, 239-248.

Mazurais D., Darias M.J., Gouillou-Coustans M.F., Le Gall M.M., Huelvan C., Desbruyères E., Quazuguel P., Cahu C. \& Zambonino-Infante J.L. (2008) Dietary vitamin mix levels influence the ossification process in European sea bass (Dicentrarchus labrax) larvae. American Journal of Physiology - Regulatory, Integrative and Comparative Physiology, 294, 520-527.

Miyashita S., Kato K., Sawada Y., Murata O., Ishitani Y., Shimizu K., Yamamoto S. \& Kumai H. (1998) Development of digestive system and digestive enzyme activities of larval and juvenile bluefin tuna, Thunnus thynnus, reared in the laboratory. Suisanzoshoku, 46, 111-120.

Morais S., Mourente G., Ortega A., Tocher J.A. \& Tocher D.R. (2011) Expression of fatty acyl desaturase and elongase genes, and evolution of DHA:EPA ratio during development of unfed larvae of Atlantic bluefin tuna (Thunnus thynnus L.). Aquaculture, 313, 129139. 
Mourente G., Tocher D.R., Diaz E., Grau A. \& Pastor E. (1999) Relationships between antioxidants, antioxidant enzyme activities and lipid peroxidation products during early development in Dentex dentex eggs and larvae. Aquaculture, 179, 309-324.

Murata H., Sakai T., Yamauchi K., Ito T., Tsuda T., Yoshida T. \& Fukudome M. (1996) In vivo lipid peroxidation levels and antioxidant activities of cultured and wild yellowtail. Fisheries Science, 62, 64-68.

Ogata Y. \& Kurokura H. (2012) Use of the freshwater rotifer Brachionus angularis as the first food for larvae of the Siamese fighting fish Betta splendens. Fisheries Science, 78, 109-112.

Overturf K. \& Hardy R.W. (2001) Myosin expression levels in trout muscle: a new method for monitoring specific growth rates for rainbow trout Oncorhynchus mykiss (Walbaum) on varied planes of nutrition. Aquaculture Research, 32, 315-322.

Papandroulakis N., Divanach P. \& Kentouri M. (2002) Enhanced biological performance of intensive sea bream (Sparus aurata) larviculture in the presence of phytoplankton with long photophase. Aquaculture 204, 45-63.

Papandroulakis N., Stefanakis S., Anastasiadis P., Ballesteros S., Papadakis I., Janssen K., Vassilakis M., Strakantounas Y. \& Divanach P. (2011) Experimental larval rearing of Atlantic bluefin tuna (Thunnus thynnus) using the mesocosm technology in the frame of the SELFDOTT project. 830-831.

Ribeiro L., Zambonino-Infante J.L., Cahu C. \& Dinis M.T. (1999) Development of digestive enzymes in larvae of Solea senegalensis, Kaup 1858. Aquaculture, 179, 465-473.

SELFDOTT (2009) From capture based to SELF-sustained aquaculture and domestication of bluefin tuna, Thunnus Thynnus (2nd periodic report of SELFDOTT project; available at http://hdl.handle.net/10508/356); last accessed February 10, 2013. 1-237.

Seoka M., Kurata M., Tamagawa R., Biswas A.K., Biswas B.K., Yong A.S.K., Kim Y.S., Ji S.C., Takii K. \& Kumal H. (2008) Dietary supplementation of salmon roe phospholipid enhances the growth and survival of Pacific bluefin tuna Thunnus orientalis larvae and juveniles. Aquaculture, 275, 225-234.

Yu H.R., Ai Q.H., Mai K.S., Ma H.M., Cahu C.L. \& Zambonino-Infante J.L. (2012) Effects of dietary protein levels on the growth, survival, amylase and trypsin activities in large yellow croaker, Pseudosciaena crocea R., larvae. Aquaculture Research, 43, 178186.

Zambonino-Infante J.L. \& Cahu C.L. (2001) Ontogeny of the gastrointestinal tract of marine fish larvae. Comparative Biochemistry and Physiology C-Toxicology \& Pharmacology, 130, 477-487.

Zambonino-Infante J.L. \& Cahu C.L. (2007) Dietary modulation of some digestive enzymes and Metabolic processes in developing marine fish: Applications to diet formulation. Aquaculture, 268, 98-105. 
Table 1- Quantity of biological materials (eggs and larvae) used for gene expression analyses at different developmental stages. Samples pooled for RNA extraction are in brackets.

Quantity of biological materials *

\begin{tabular}{|c|c|c|c|}
\hline Rearing location & Mazarron & Heraklion & Palavas \\
\hline Type of rearing & $\begin{array}{c}\text { pseudo green } \\
\text { water }\end{array}$ & $\begin{array}{l}\text { Mesocosm or } \\
\text { pseudo green } \\
\text { water(\#) }\end{array}$ & Clear water \\
\hline Hatching & $60+42+54 \mathrm{mg}$ & $88+163+66 \mathrm{mg}$ & $(22+24)+31 \mathrm{mg}$ \\
\hline Mouth opening & $54+83+76 \mathrm{mg}$ & $54+66+78 \mathrm{mg}$ & $(16+14)+42 \mathrm{mg}$ \\
\hline $5 \mathrm{dph}$ & - & - & $28+30+42+39 \mathrm{mg}$ \\
\hline $10 \mathrm{dph}$ & $(24+26)+28 \mathrm{mg}$ & $37+50+37+24^{\#} \mathrm{mg}$ & $51+67+106+49 \mathrm{mg}$ \\
\hline $15 \mathrm{dph}$ & $80+85+80 \mathrm{mg}$ & $28+21+23^{\#} \mathrm{mg}$ & $76+62+80+111 \mathrm{mg}$ \\
\hline $20 \mathrm{dph}$ & $85+95+80 \mathrm{mg}$ & $23+45^{\#} \mathrm{mg}$ & - \\
\hline
\end{tabular}

* Two, three or four pools of larvae were analysed per stage for each hatcheries 
Table 2: Oligonucleotide primer sequences

\begin{tabular}{cccc}
\hline Gene & Tm $^{*}$ & Forward and reverse primers & Accession number \\
\hline EF1c & 60 & $\begin{array}{l}\text { CATTGACATCGCTCTGTGGA } \\
\text { TGATGACCTGRGCGTTGAG }\end{array}$ & \\
\hline ANPEPc & 57 & $\begin{array}{l}\text { AGCGDGTACATGGAGAAYGG } \\
\text { GAAGRTCCCTTGCTGTARGA }\end{array}$ & \\
\hline AMYc & 51 & $\begin{array}{l}\text { TTYGAGTGGCGCTGG } \\
\text { RGGCCACATGTGCTT }\end{array}$ & \\
\hline TRYP1c & 59 & $\begin{array}{l}\text { CAGGTGTCTCTGAACTCTGG } \\
\text { CCCARGACACAACACCCTG }\end{array}$ & \\
\hline CATc & 51 & $\begin{array}{l}\text { TGACATGGTGTGGGACTTCTGG } \\
\text { CTTGTAGTGGAACTTGCAGTAG }\end{array}$ & FM995222.1 \\
\hline EF1q & 60 & $\begin{array}{l}\text { CCCCTGGACACAGAGACTTC } \\
\text { GCCGTTCTTGGAGATACCAG }\end{array}$ & FM995223.1 \\
\hline ANPEPq & 60 & $\begin{array}{l}\text { CCTGAGGTGGTGGAATGACT } \\
\text { GGGTTCAGCTTTGTCTGCTC }\end{array}$ & FM995224.1 \\
\hline AMYq & 60 & $\begin{array}{l}\text { TCATGTGGAAGCTGGTTCAG } \\
\text { AATATTGCCACTGCCAGTCC }\end{array}$ \\
\hline TRYP1q & 60 & $\begin{array}{l}\text { CCCCAACTACAACCCCTACA } \\
\text { CCAGCCAGAGACAAGACACA }\end{array}$ & FM995227.1 \\
\hline CATq & 60 & $\begin{array}{l}\text { ATGGTGTGGGACTTCTGGAG } \\
\text { ATGAAACGGTAGCCATCAGG }\end{array}$ & D85138.1 \\
\hline MYH2q & 60 & $\begin{array}{l}\text { GATTCAGCTGAGCCATGCCA } \\
\text { TCTCAGCTCCTCAATCTCAG }\end{array}$
\end{tabular}

c: Oligonucleotide primers used for cloning-PCR.

q: Oligonucleotide primers used for real time-PCR.

*: annealing temperature used during PCR for each couples of primers

\#: cloned by Hirayama Y. and Watabe S.

$\$$ : sequence with less than 200 nucleotides can not be submitted to genbank databasis 
Table 3 : Nucleotide similarity (as determined by e-value using Blastn) between the bluefin tuna EF1a, TRYP1, AMY, ANPEP, and CAT partial sequences cloned and their respective reported orthologs in other species

\begin{tabular}{|c|c|c|c|c|}
\hline Gene name & Full name & $\begin{array}{l}\text { Accession number } \\
\text { of bluefin tuna } \\
\text { partial sequence } \\
\text { cloned }\end{array}$ & $\begin{array}{c}\text { Accession number of } \\
\text { orthologs in other } \\
\text { species }\end{array}$ & e-value \\
\hline EF1a & $\begin{array}{c}\text { elongation factor } 1 \\
\text { alpha }\end{array}$ & FM995222.1 & $\begin{array}{c}\text { Seriola } \\
\text { quinqueradiata } \\
\text { AB032900.1 }\end{array}$ & 0.0 \\
\hline TRYP1 & trypsinogen 1 & FM995227.1 & $\begin{array}{c}\text { Thunnus orientalis } \\
\text { AB678422.1 }\end{array}$ & 0.0 \\
\hline AMY & alpha-amylase 2 & FM995224.1 & $\begin{array}{c}\text { Thunnus orientalis } \\
\text { AB678420.1 }\end{array}$ & 0.0 \\
\hline ANPEP & aminopeptidase $\mathrm{N}$ & FM995223.1 & $\begin{array}{c}\text { Dicentrarchus labrax } \\
\text { FJ860001.1 }\end{array}$ & 0.0 \\
\hline CAT & catalase & $\$$ & $\begin{array}{c}\text { Oplegnathus } \\
\text { fasciatus } \\
\text { AY734528.1 }\end{array}$ & $1 e-60$ \\
\hline
\end{tabular}

\$: sequence with less than 200 nucleotides can not be submitted to genbank databasis

\section{Figures}

Figure 1- The mean growth curve (length data in $\mathrm{mm}$ ) of Atlantic bluefin tuna (Thunnus thynnus) larvae collected from all rearing conditions between hatching and $20 \mathrm{dph}$. Error bars represent the standard deviation of the mean.

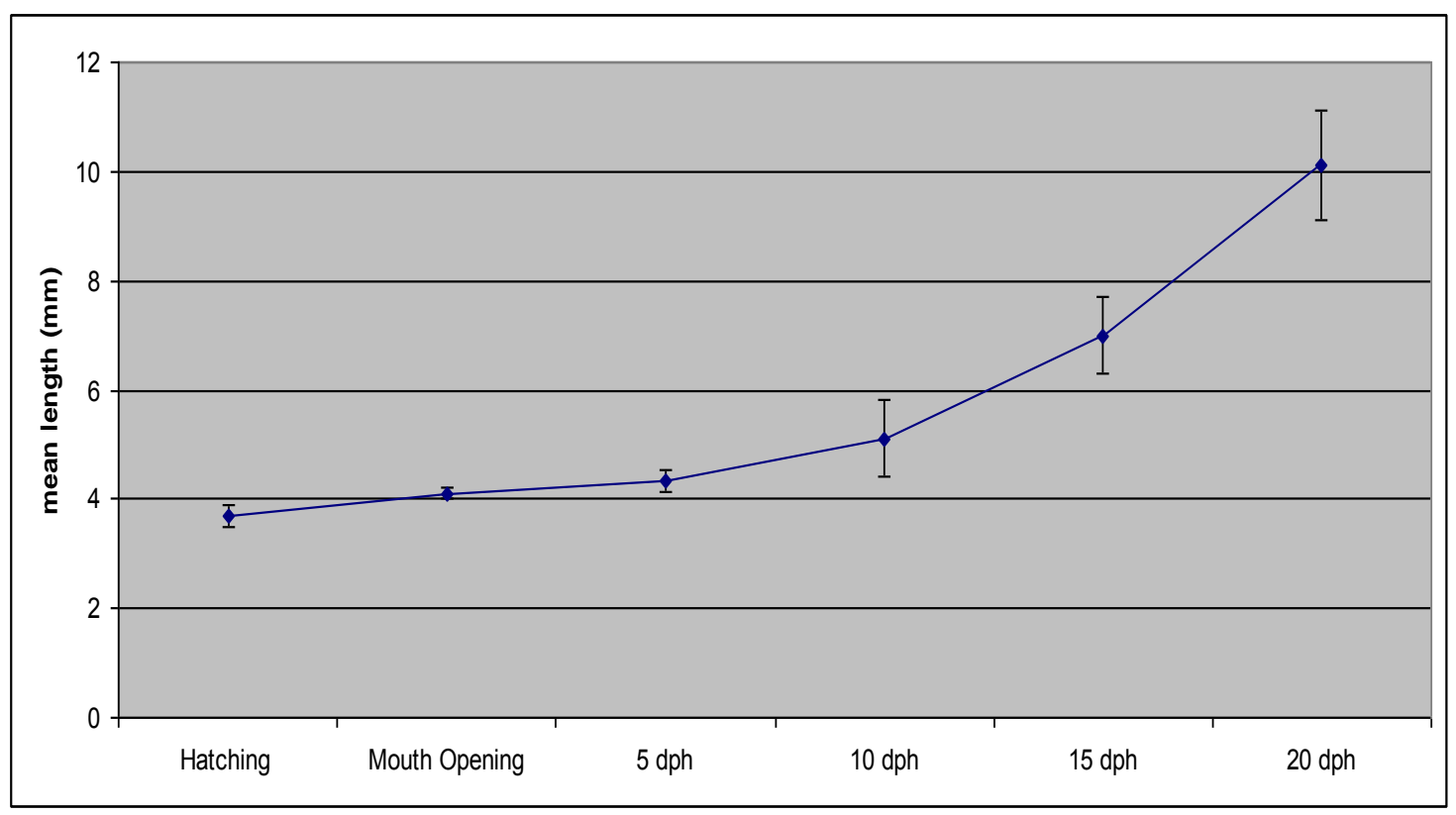


Figure 2- Relative level of mRNA encoding for myosin heavy chain (2A), alpha amylase (2B), trypsin (2C), ANPEP (2D) and catalase (2E) during Atlantic bluefin tuna (Thunnus thynnus) development, from hatching to $20 \mathrm{dph}$. Error bars represent the standard deviation of the mean. Means with the same letter are not significantly different.

Figure 2A

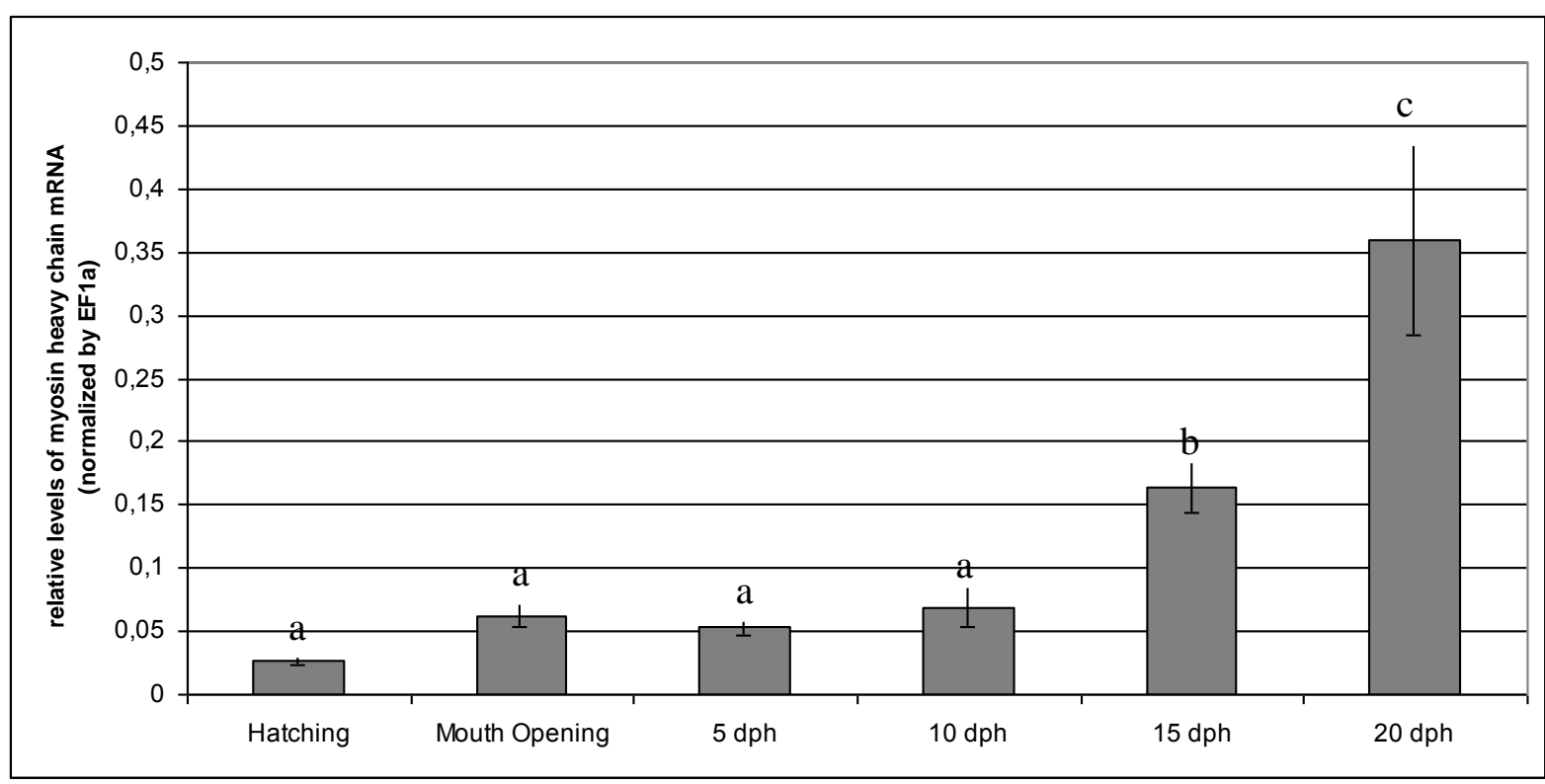

Figure 2B

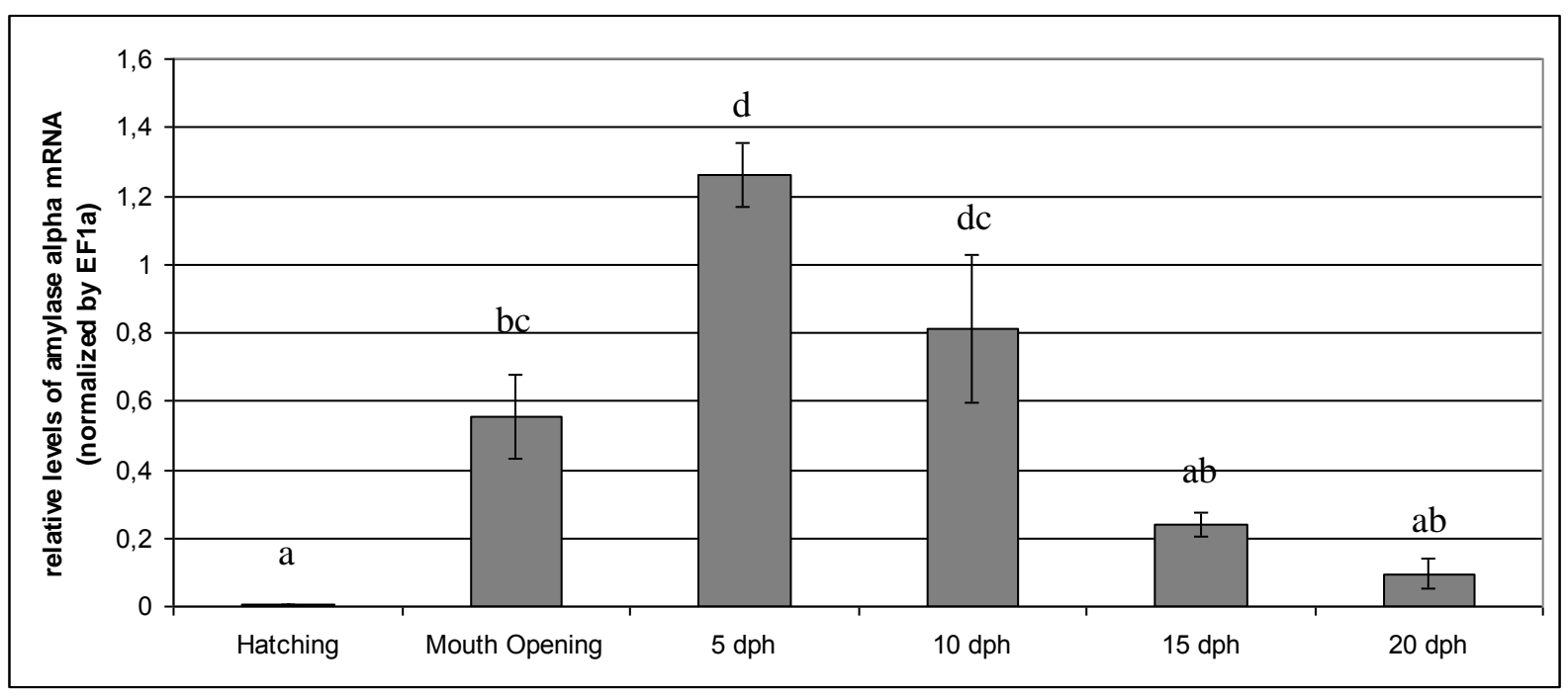


Figure 2C

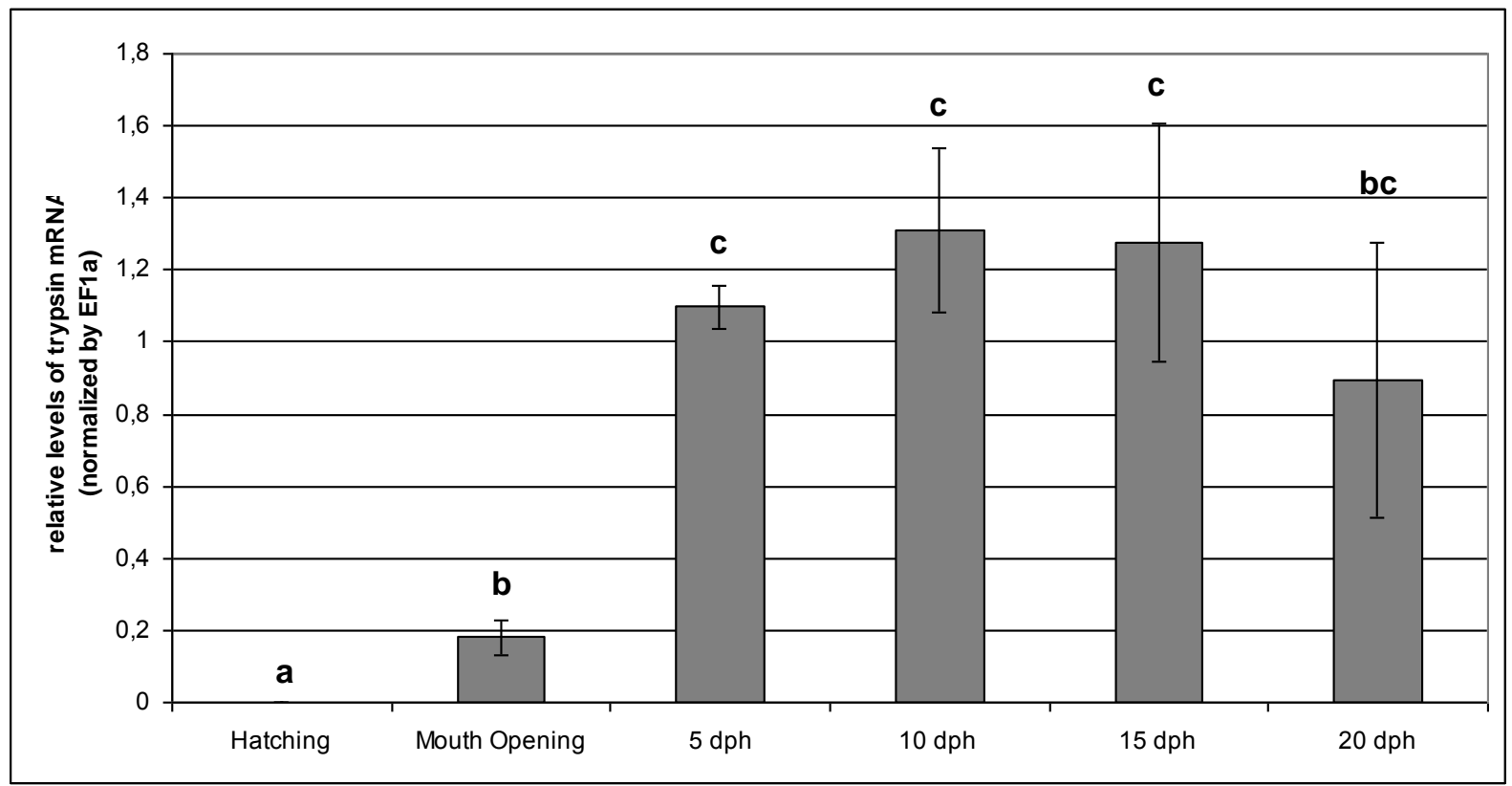

Figure 2D

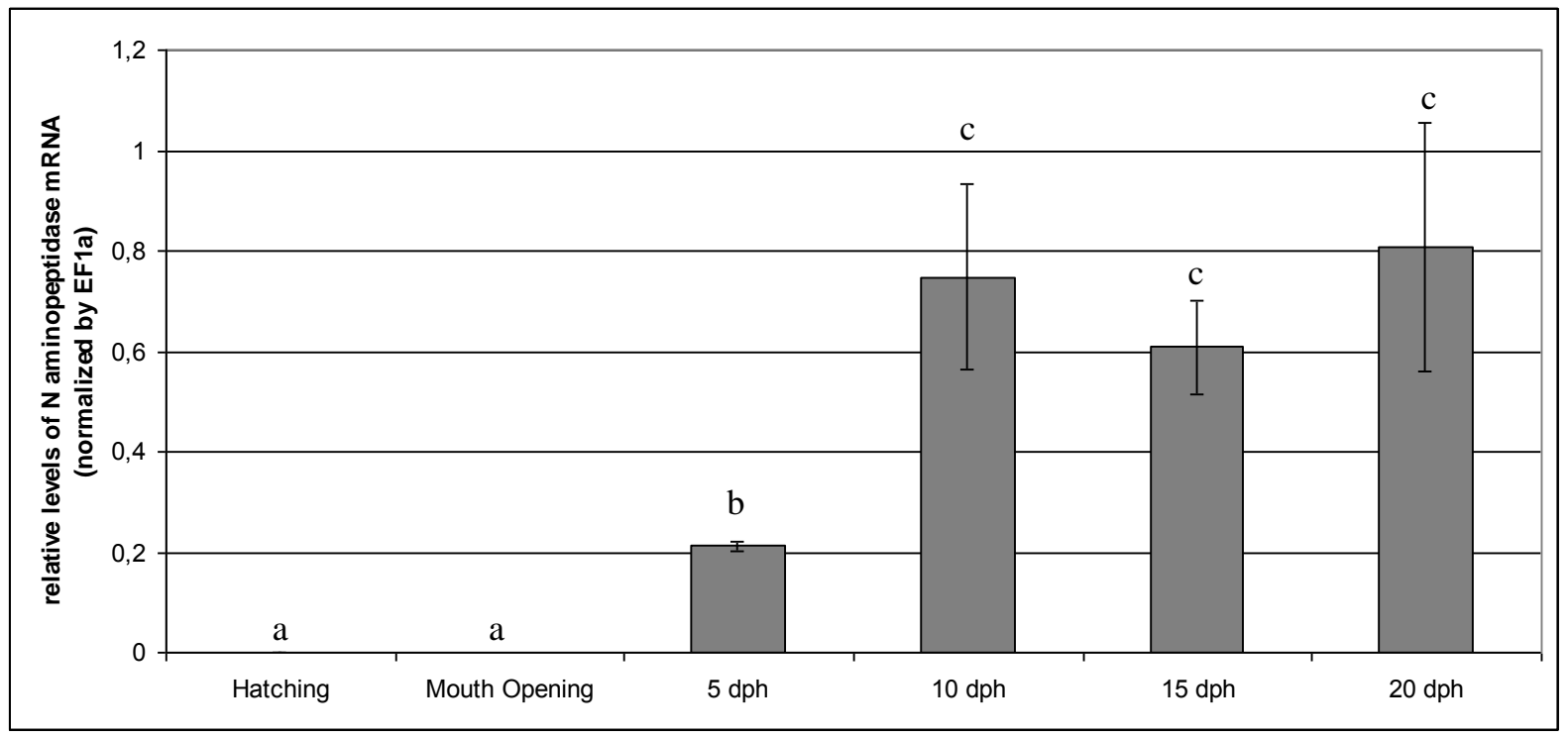


Figure 2E

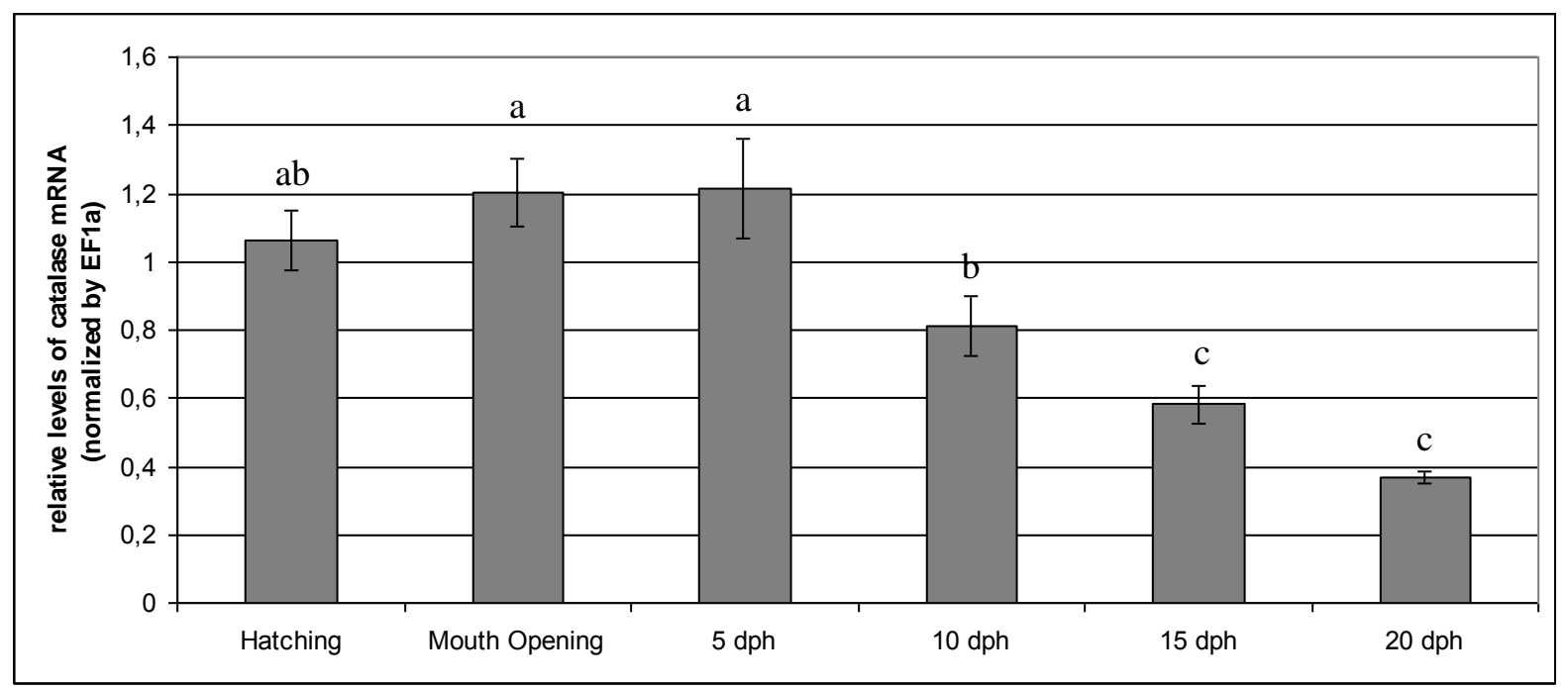

